しかし外力が作用した後の応力分布の变化にはふれて

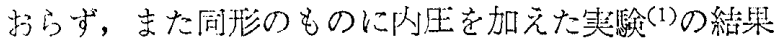
とも此較してはいない。

(1) J. Appl. Mech., 25-2 (1958-6).

[兒田平八]

$539.4 .019 .1: 620.178 .152 .5$

†[608]動的かたさからのひずみ速度依存性の決定

[C.D. Davis \& S.C. Hunter, Sheet Metal Indust., 1962, Vol. 39, No. 420, p. 261 263, 図 2, 㳼 1]

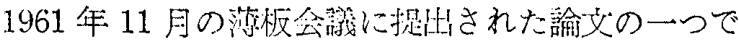

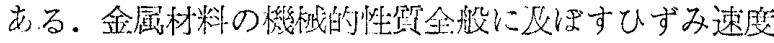

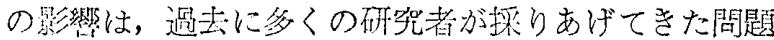
である。ここでは静的と動的なかたさ試駼を行ない， そのかたさの比をもって，その材料のひずみ速隻によ る供存度を定義している。

実験方法は，約 $1 \mathrm{~kg}$ の展り子に円すい状（半角 $45^{\circ}$, $68^{\circ}$ の 2 種）圧子を取付け， $30 \mathrm{~cm} / \mathrm{s}$ までの速さで， $100 \mathrm{~kg}$ の土台に取付けた 0.1 in 厚さの各種試片にふ心 つ村る。

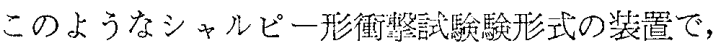

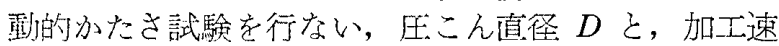

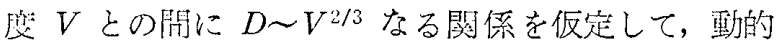
かたさを定諘している。動的かたさそのものを，ひず

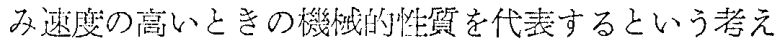

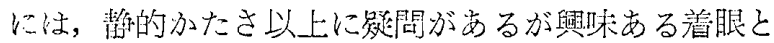
考えられる。

玨子の円すい解による造いはなく，静的かたさ $H_{s}$ 々動的かたさ $H_{d}$ の比， $H_{d} / H_{s}$ は，モリブデンで 1.7, アームコ铁 1.5 を最高に，アルミニウム合金 $1.1 〜$ 1.2 , ニッケル，鉄合金(インバール) $1.1 \sim 1.2$, が最 低佂として示されている。

[清野 次郎]

$539.42: 678.742 .2$

$\dagger[609]$ ポリエチレンの環境応力き裂〔P. Hittmair \& R. Ullman, J. Appl. Polymer Sci, 1962-1/2, Vol. 6, No. 19, p. 1〜14, 四 9, 表 7] プラスチックの

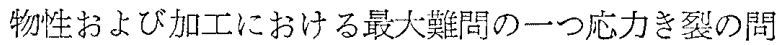
題について，ポリエテレンについての実験己考察をま とめたもので，J. Howard の報告(1)以来の性作であ る、温度とデタージェントを变えられるようにしたい ろいろの環境中に板状試験片に一定応力を加えた時の き致発生を観祭する。この場合板状試験片には一円子 を非刘称にもたせて応力集中を起こさせるようにして ある. Igepal やノルマルヘプタン等のデタージェン 卜を用いて円孔問辺の鼠大応力部よりのき裂の発生が

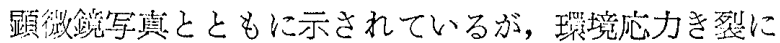

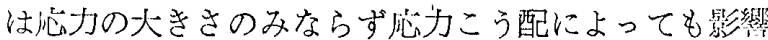
されることがわかった，結晶化度，分子量の大きさの 罢疗るいろいろのポリエチレンについて温度，デター

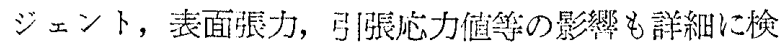

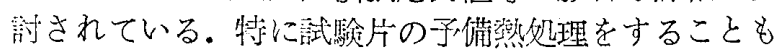

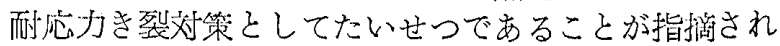
ている。

(1) J. Howard, SPE J., 15, (1959), 397.

$678.01: 620.172 .251 .225$

[伊藤 勝宸]

†[610] 伸び变形対温度 (T.D.T.) 試験による軟化点

の決定 [D.J.H. Sandiford \& K.A. Buckingham,
British Plastics, 1961-11, Vol. 34, No. 11, p. 594

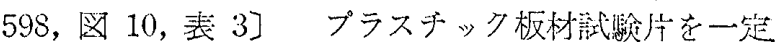

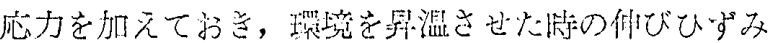

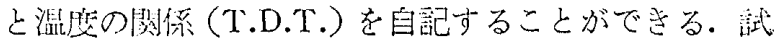

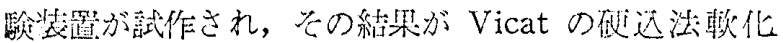

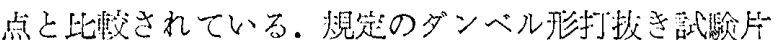
は油浴（ICI シリコーン泊健用）中で $2^{\circ} \mathrm{C} / \mathrm{min} の 一$

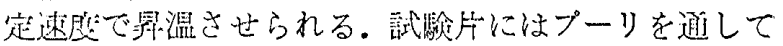

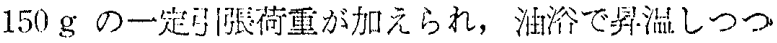

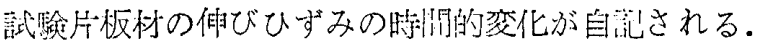

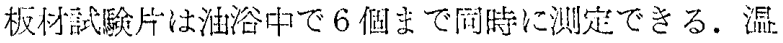

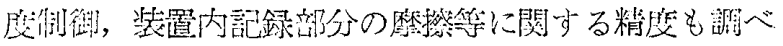
られている。ポりカーポネイト，海化ビニル肖独重会 樹指および共重合(酶酸ビニル)樹脂，アクリル樹脂，

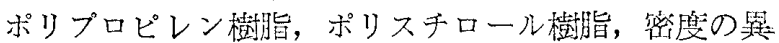
なる各硾ポリエテレン樹脂等の各種熱可塑性樹脂が言式

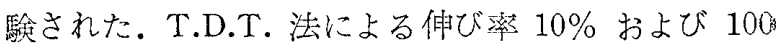
$\%$ に対する温度 $T_{10}$ および $T_{100}$ を押込深さ $1 / 10 \mathrm{~mm}$ および $1 \mathrm{~mm}$ に対するVicat 靯化点とそれぞれ対芯 させているが，一般にT.D.T.法による軟化点の方㤎 数 ${ }^{\circ} \mathrm{C}$ 高いようである。

\section{[伊藤 勝彥]}

†[611] 金属の弓張応力ーひずみ関係およびその他に 及ぼすひずみ速度の影響 [H.G. Baron, Sheet Metat Indust., 1962, Vol. 39, No. 420, p. 257 260, 264 〜266, 図 9] 1961 年 11 月に Birmingham に抒 いて開かれた薄板に関する会議に提出された論文であ る. Baron 自身忍(1)，先に詳細に述べた報告の紹介を 中心にして，20 年首ijの Manjoin \& Nadai の高速引 張試験に関する存名な諭文から始まり，多くのこの方 面の研究を採りあげている，檢傠している内容は，号 張応力ーひずみ曲線の形状，降伏点，延性，限界衝整 速度，变形双晶等である。

またこれら各項目の本坴告と，同じ会議に提出され， た静的, 動的かたさの比より，ひずみ速度の依存度を 決める報告の二つについての傠論妾最後の 3 ページに わたり揭載している。この多勢の人々による討論のと ころで，ひずみ速度の大なるときの泦力ーひずみ線 上で, 最大地力以後急速小地力低下法, Baronの唱え

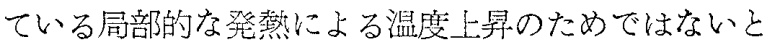
指摘されているまた高いひずみ速度では，一般に応 力が大上なってくる汸，この点に関して訪明が不十分 であることも討論中で述べられている。

(1) H.G. Baron, J. Iron. Steel Inst., 32, (1956).

[清野次郎]

\section{$539.42: 620.165 .2: 669.14-46$}

$\dagger[612$ 厚肉高圧容器の破損 [E. Saibel, Indust Engng. Chem., 1961-12, Vol. 53, No. 12, p. 975

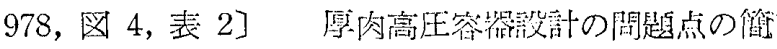
単な解説と，実例としてオートクレーブの水王試駼に よる破壊例とその改善策の一例をあげたものである。

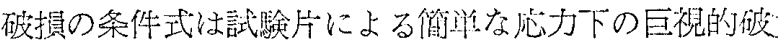

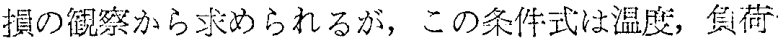

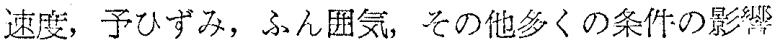

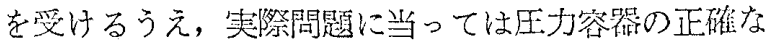
応力状態の計算がきわめて因難である。また破攅煺 られた部分から始まるため，産分的な条件によって破 